\title{
Organic matter characteristics of Cenomanian-Turonian source rocks: implications for petroleum and gas exploration onshore Senegal
}

\author{
P. Nzoussi-Mbassani, J. -R. Disnar and F. Laggoun-Défarge \\ Institut des Sciences de la Terre d'Orléans (ISTO), UMR 6113 du CNRS, Université \\ d'Orléans, Bâtiment de Géosciences, 45067, Orléans cedex 2, France
}

\section{Abstract}

One hundred and fifteen samples of Cenomanian-Turonian sediments from the Senegal margin basin, believed to be the main source rocks in the area, have been characterised to determine their organic facies and their oil-generating potential. The samples have been subjected to detailed organic petrographic studies (palynofacies, maceral analysis, vitrinite reflectance measurements) combined with Rock-Eval and Leco determinations. Total organic carbon values comprised between 0.3 and $3.5 \%$ indicate poor to moderate primary bioproductivity and/or unfavourable organic matter $(\mathrm{OM})$ preservation. Rather high $\mathrm{C} / \mathrm{N}$ ratio values supported by the presence of well preserved ligno-cellulosic debris and of collotelinite suggest a notable contribution of terrestrial OM. This is supported by hydrogen and oxygen index values that testify to type III OM. S/C ratio values lower than 0.36 together with the presence of abundant reworked organic particles indicate that the studied sediments were deposited in a transitional and mixing zone, between a coastal area with well oxygenated waters and a fully marine environment with more or less pronounced anoxia. The rather low marine productivity and poor OM preservation are here strongly reinforced by a very marked dilution of the OM by mineral inputs. In addition to these combined factors indicating that the $\mathrm{OM}$ is mainly of the gas prone-type, a moderate maturity is shown by $T_{\max }$ and vitrinite reflectance values ranging from 435 to $445{ }^{\circ} \mathrm{C}$ and 0.4 to $0.9 \%$, respectively. The reservoir facies consisting of sandstones interbedded with shales, are characteristic of prograding fluvio-deltaic formations developed during Maastrichtian regression. Faults and 'rollover' structures most probably constitute the main migration pathways and traps for hydrocarbons, respectively. Overall, the characteristics of the studied formations highlight the importance of local factors in $\mathrm{OM}$ accumulation, even during the so-called global Cenomanian-Turonian anoxic event.

Author Keywords: Cenomanian-Turonian of the Senegal margin basin; Organic matter sources; Depositional environment; Petroleum source rock 


\section{Introduction}

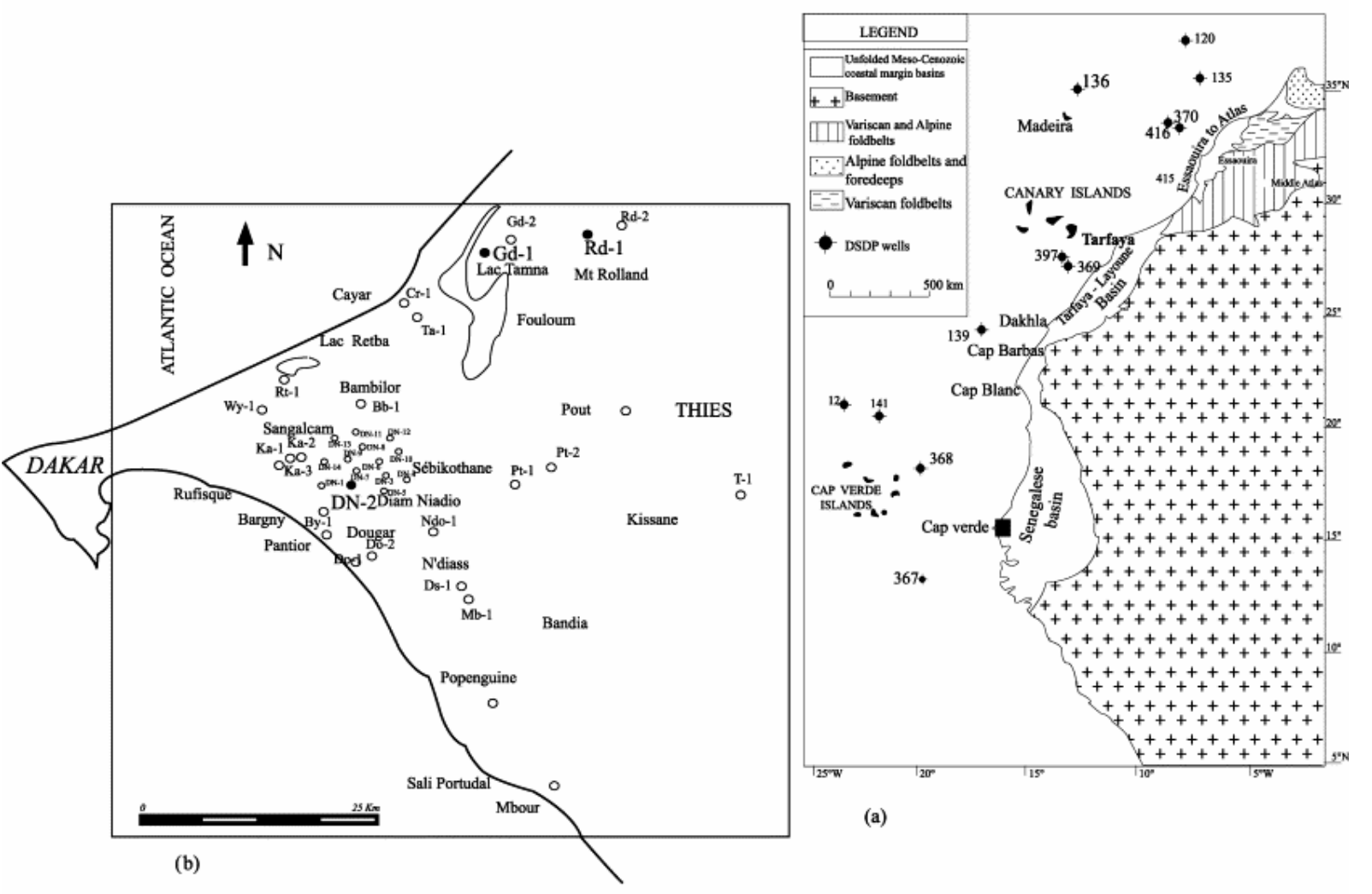

Fig. 1. (a) Map showing generalised geological setting of west African margin and the location of Thies-Diam Niadio study area within Senegalese basin. (b) Location of the boreholes within the Thies-Diam Niadio area (full circles show the three studied wells, i.e. DN-2, Gd-1, Rd-1).

The Thies-Diam Niadio area covers a surface of $6602 \mathrm{~km}^{2}$ on the onshore part of the Senegal basin (Fig. 1). Oil shows in this area have been recorded as bituminous traces at outcrops and from water wells since 1917. Petroleum exploration begun late in 1952 and the first well was drilled in 1953. To date more than 46 wells have been drilled in this area where CenomanianTuronian rocks are thought to be the main hydrocarbon source rocks.

The importance of the so-called Cenomanian-Turonian anoxic event in source rock accumulation has been widely recognised and has given rise to an abundant literature ([Jenkyns, 1980, de Graciansky et al., 1982 and Herbin et al., 1986]). Different factors have been proposed to explain the global extent of this phenomenon: tectonics and topography ( [Arthur and Schlanger, 1979]), ocean water stratification ( [Jenkyns, 1980 and Lancelot, 1980]), climatic conditions and oceanic water circulation ( [Busson, 1972]), high planktonic production ( [Tissot, 1979a and Tissot, 1979b]), euxinism ( [Waples, 1983]), establishment of an oxygen minimum zone ( [Thiede and Van Andel, 1977]), mantle $\mathrm{CO}_{2}$ emission and sea water stratification ([Busson and Cornée, 1996]) and a combination of several of these factors ( [de Graciansky et al., 1984]). Despite diverging opinions, numerous authors agree that this so-called anoxic event had a global impact and that oxygen deficiency of oceanic waters was primarily caused by abundant planktonic production. 
While the study of Cenomanian-Turonian sediments drilled offshore Senegal during the Deep Sea Drilling Project revealed their richness in organic matter ([Herbin et al., 1986]), the extension of this event to the whole basin and especially to the onshore part, is not yet well understood. In addition, in spite of an already rather long exploration history, several aspects of petroleum generation and expulsion from Cenomanian-Turonian formations in this area, still remain obscure. One of the main enigmas addressed in this paper, concerns the nature and the diagenetic history of the organic matter believed to be the source of hydrocarbons exploited in Senegal.

\section{Geological setting}

Some $340,000 \mathrm{~km}^{2}$ in area, the Senegal sedimentary basin occupies the central part of the large north-western Africa basin which extends along the Senegal, Gambia, Guinea-Bissau, Mauritania and Moroccan coastal areas (i․ 1). The basin opens westward to the Atlantic ocean and it is limited by the Panafrican to Hercynian Mauritanides chain to the East ( [Dillon and Sougy, 1974 and Villeneuve and Da Rocha Araujo, 1984]).

It is a typical passive divergent continental margin subjected initially to extension in Triassic times, when rifting of Africa from America commenced ([Pitman and Talwani, 1972]). It contains more than $14 \mathrm{~km}$ thick Paleozoic to Tertiary sediments. Outcrops are rare and the known stratigraphy is based on deep wells. Three main phases characterise the geological history of the Senegal basin and different kinematic models have been proposed to explain the formation of such Atlantic-type continental margins ( [Kinsman, 1975, Falvey, 1974 and McKenzie, 1978]). In the Senegal basin the pre-rift phase is mainly represented by late Proterozoic and Paleozoic clastics sediments. The most complete Paleozoic section was characterised in the Diana-Malari (DM-1) and Kolda (KO-1) wells. These sediments were affected by the Panafrican (1000-570 Ma) and Caledonian-Hercynian (440-250 Ma) orogenies ( [Villeneuve and Da Rocha Araujo, 1984]).

The syn-rift phase commonly associated with a thermal uplift of the mantle, begun with the formation of horst and graben structures followed by the break up of Gondwana. The graben system was filled by lower Triassic continental sandstones and lacustrine shales. Restricted marine conditions also led to the deposition of upper Triassic to Lower Liassic salt deposits. Unlike the adjacent Mauritanian basin, Upper Liassic to Lower Dogger clastic formations are absent. The last or post-rift phase began with the separation of the Gondwana lithosphere and the initiation of the Atlantic ocean. [Falvey, 1974] suggested that the syn-rift and post-rift phases are separated by an unconformity. The absence of the uppermost syn-rift in the Senegal basin might be due to this unconformity. The thickness of the post-rift sedimentary wedge can exceed $10,000 \mathrm{~m}$ in the western part of the basin. It consists of transgressive and regressive series successively comprising: (i) a Jurassic-Lower Cretaceous carbonate platform, (ii) a Cretaceous clastic wedge, and (iii) a cap of Tertiary carbonates and shales ( [Michaud, 1984]).

Regional seismic profiles and well data successively revealed the stratigraphic and lithologic composition of these formations. Three facies characterise the lateral variations of the Cenomanian-Turonian sediments. The first consists of homogenous black shales deposited in fully marine environment. This facies dominates the western part of the Thies-Diam Niadio area and reaches maximum thickness in Casamance. No well has reached the base of this facies in the study area. However seismic profiles suggest a basinward increase in its thickness. The second facies is characterised by a succession of calcareous and shaly 
calcareous sediments typical of a transitional neritic environment. The third facies, typical of a sub-littoral to nearshore marine environment, is composed of shales with shaly siltstone intercalations. These sediments become increasingly rich in siltstone towards the shoreline.

\section{Methods}

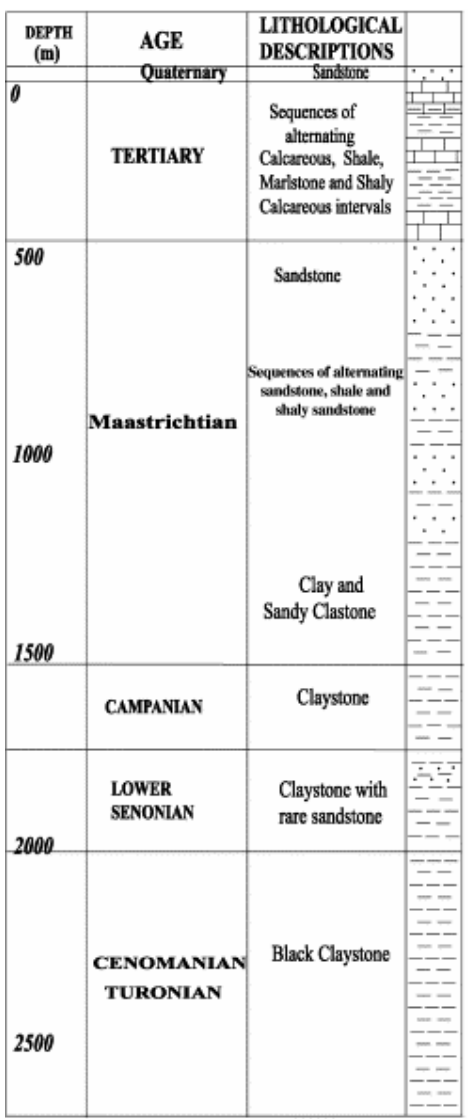

(a)

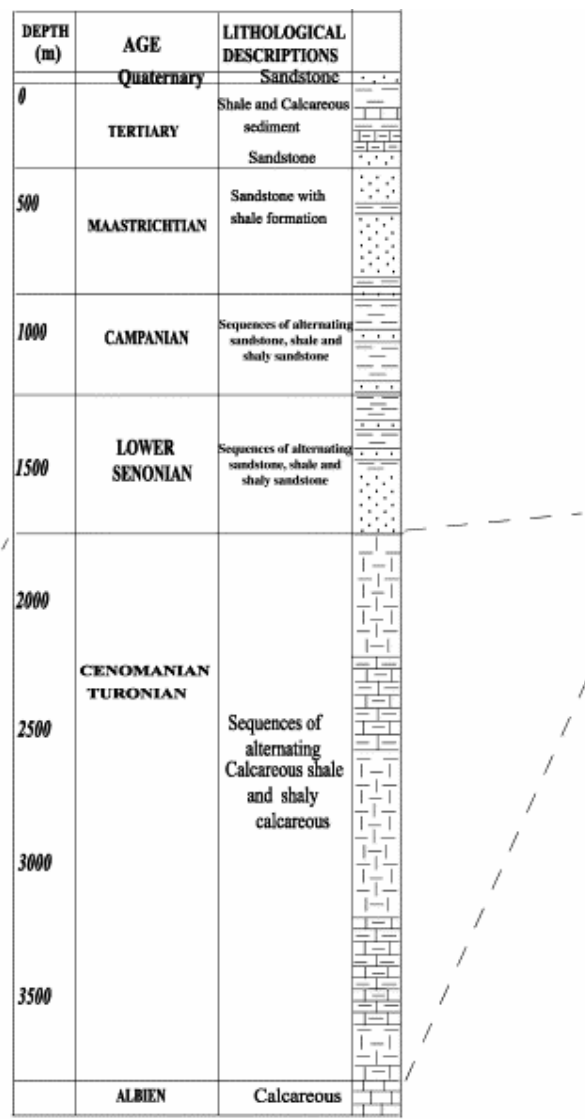

(b)

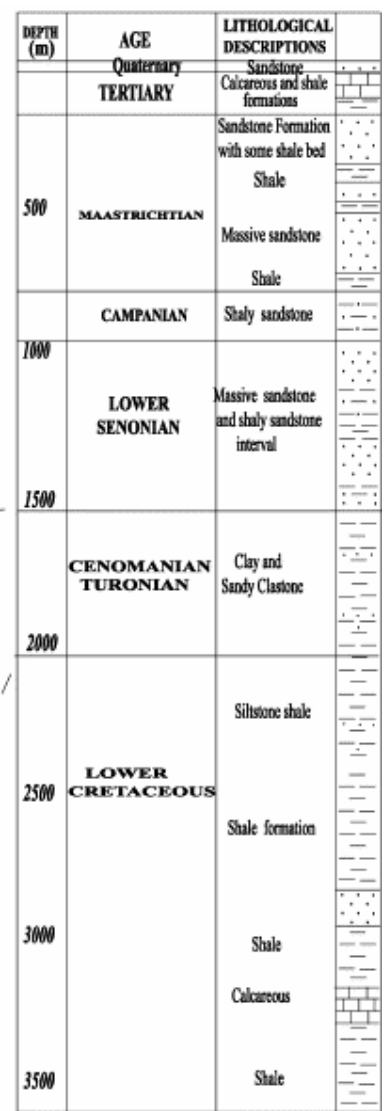

(c)

Fig. 2. Lithological descriptions of boreholes with the main Cenomanian-Turonian facies: (a) DN-2 well in distal environment, (b) Gd-1 transitional neretic environment, (c) Rd-1 littoral and nearshore area.

One hundred and fifteen samples of drill cuttings were collected from the three wells DN-2, Gd-1, Rd-1 (Fig. 1 and Fig. 2) which penetrated one of the main facies of the CenomanianTuronian formation in the area

Total Organic Carbon (TOC) contents (wt\%), Hydrogen Index (HI, mg $\mathrm{HC} \mathrm{g}^{-1} \mathrm{TOC}$ ), Oxygen Index (OI, mgCO $\left.\mathrm{g}^{-1} \mathrm{TOC}\right), T_{\max }\left({ }^{\circ} \mathrm{C}\right)$ and Petroleum Potential (PI) were determined by Rock-Eval ${ }^{\circledR}$ pyrolysis ([Espitalié et al., 1985]; [Lafargue et al., 1998]) with a model 6 device (Vinci Technologies). The analyses were carried out on $100 \mathrm{mg}$ of crushed samples under standard conditions. Total $\mathrm{C}$ (TC), $\mathrm{N}$ and $\mathrm{S}$ were also determined by combustion with a Leco CNS 2000 analyser, without previous decarbonation.

Petrographic studies of organic matter were performed using a Leica DMR XP microscope under different illumination modes: identification and counting of organic constituents were 
carried out on total organic matter after acid hydrolysis of carbonates and silicates under transmitted light (palynofacies). Specific characterisation (maceral analysis) of land-derived organic particles, i.e. mainly vitrinite and inertinite groups, was performed on polished sections of densimetric concentrates of OM under reflected light and fluorescence, following the nomenclatures of [Stach et al., 1982] and the International Commission for Coal Petrology procedures [ICCP, 1971]. Random vitrinite measurements $\left(R_{\mathrm{r}}\right.$ expressed in \%) were made on the same densimetric concentrates under reflected light using a $\times 50$ oil immersion objective [ICCP, 1971].

\section{Results and discussion}

TOC contents are usually rather low and vary between 0.3 and 3.5\%. Maximum values were found in the DN-2 well which penetrated the more marine facies. TOC is roughly correlated to lithofacies variations: it appears slightly higher in pure shale $(1.7 \%$ on average in $\mathrm{DN}-2)$ than in shaly limestones $(1.3 \%$ on average in Gd-1) or shaly siltstones $(1.4 \%$ on average in Rd-1). Overall, TOC data do not show very significant difference in OM accumulation between the open marine environment (DN-2) and shallow marine deposits (Rd-1). Total Carbon (TC) contents which remain also rather low in the three wells studied $(<5.0 \%)$ mostly denote the very low level or even total absence of carbonates in the drilled formations. However, in contrast to the DN-2 and Rd-1 wells which show a good correlation between TC and TOC, Gd-1 does not. (Fig. 3). In the latter well, TC values which are sometimes higher than TOC's obviously reflect a minor mineral carbon contribution. Mineral carbon contents which can be taken as the difference between TC (Leco) and TOC (Rock-Eval) correspond to lithologic alternances of shales and carbonated shales observed in the Gd-1 well (Fig. 2).

Total sulphur contents also show some disparity between the three wells. The DN-2 well shows higher sulphur contents and S/C ratios (Fig. 4) that suggest a greater development of anoxic conditions in the distal part of the basin. However, if one excepts some levels in the $\mathrm{DN}-2$ and $\mathrm{Rd}-1$ wells, $\mathrm{S} / \mathrm{C}$ ratio values are generally lower than 0.36 , suggesting that the deposition mostly occurred under medium oxic conditions (Fig. 4; [Raiswell and Berner, 1985, Raiswell et al., 1988, Minster et al., 1992 and Morse and Berner, 1995]). The contrast between such conditions and the pronounced anoxia under which the Cenomanian-Turonian formations are believed to have been deposited in the nearby Senegal basin ( [ $\underline{\text { Herbin and }}$ Deroo, 1982]) suggest efficient oxygenation of waters by current circulation during this period.

The mineral sulphur contents are probably mostly or even totally due to generally isolated pyrite framboids. Higher proportions of framboidal pyrite $(>10 \%$, ) determined from palynofacies analyses are found in DN-2 than in Rd-1 and Gd-1 (Fig. 5). Despite the simultaneous increase of pyrite and total sulphur contents in the DN-2 well, the absence of correlation between total sulphur and pyrite suggests that sulphur most probably also exists under an organic form via the so-called 'natural sulfuration process', during early diagenesis, ([Boussafir and Lallier-Vergès, 1997 and Tribovillard et al., 1994]). 

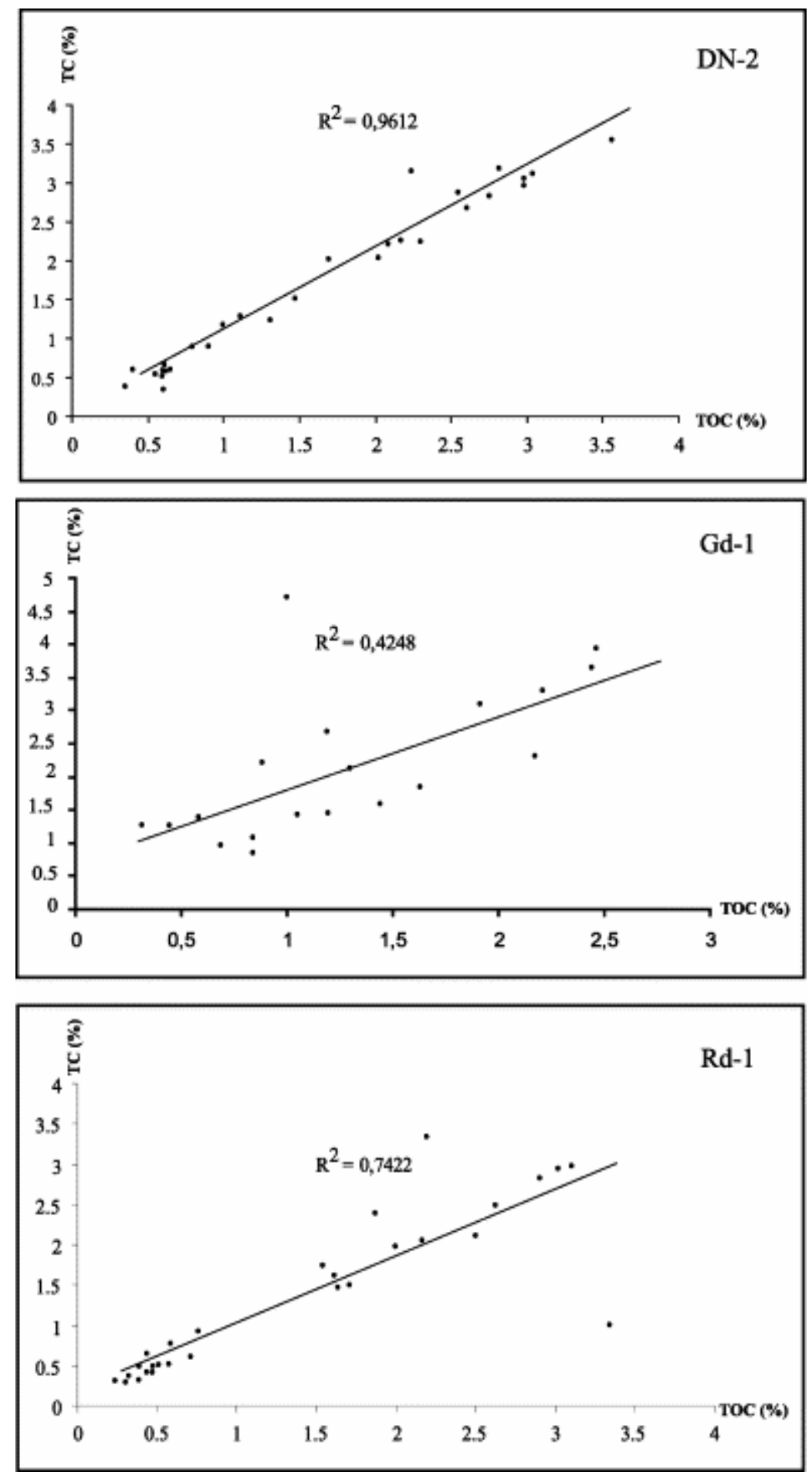

Fig. 3. Correlation between total carbon (TC) contents obtained from Leco CNS 2000 analyser and total organic carbon (TOC) yield obtained from Rock-Eval pyrolysis. 


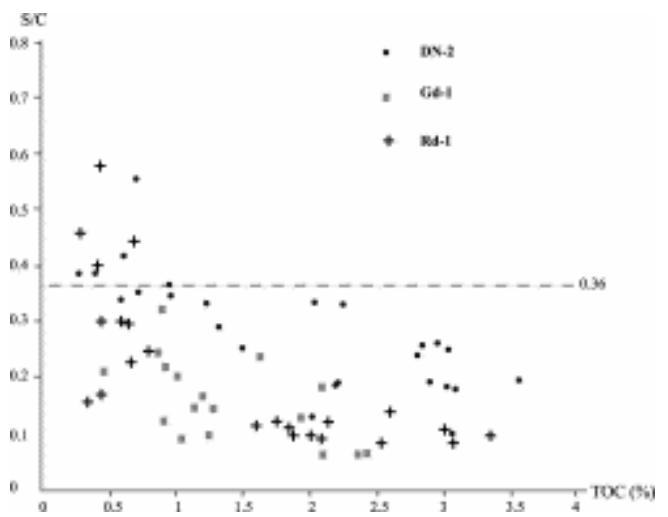

Fig. 4. Sulfur and carbon ratio (S/C) vs total organic carbon (TOC) indicating medium oxic conditions.

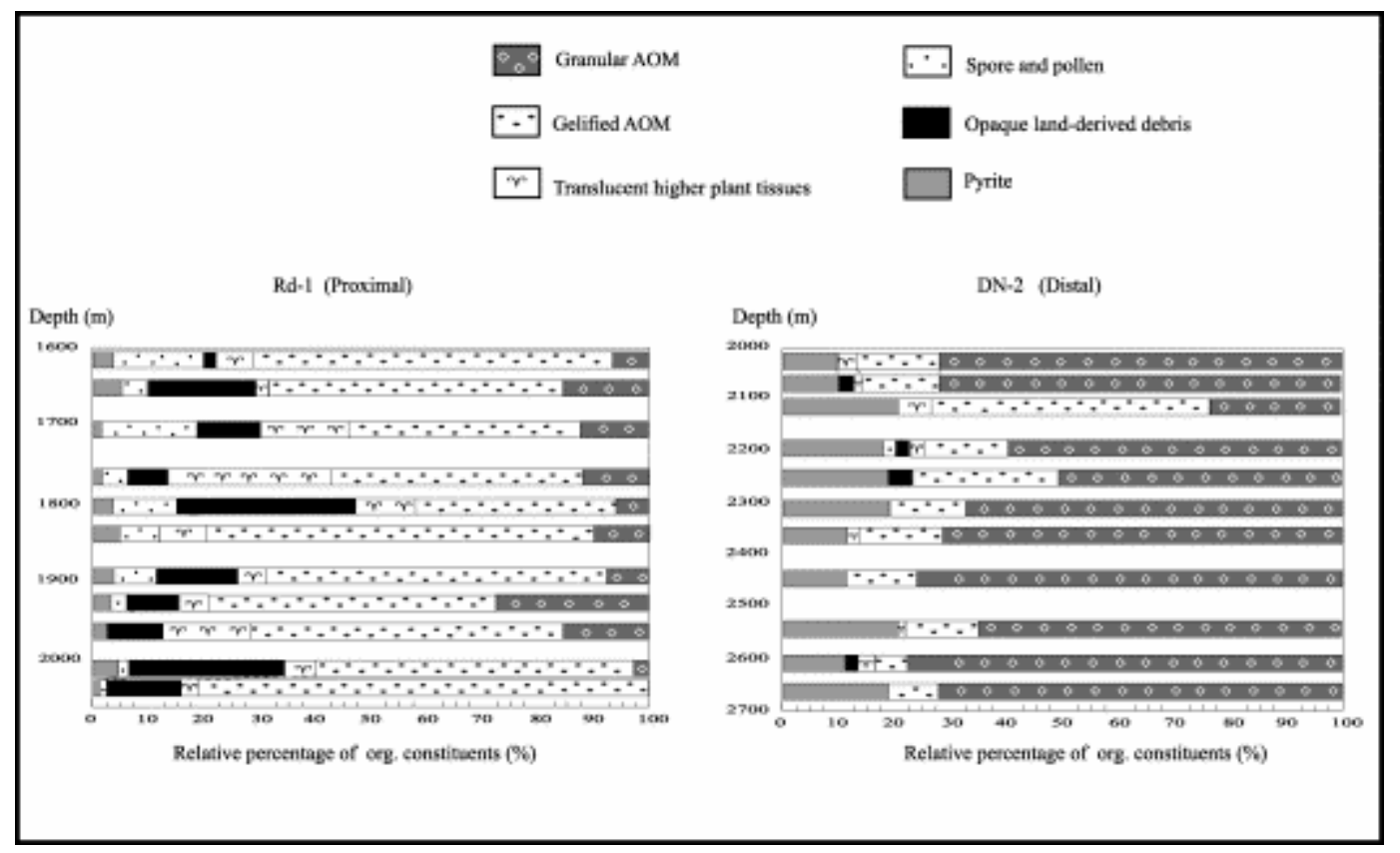

Fig. 5. Relative abundance of organic constituents (palynofacies) from proximal (Rd-1) to distal (DN-2) environment. Predominance of amorphous organic matter (AOM) with two main groups: gelified (glAOM) in proximal environment and granular (grAOM) in distal one. 
$\mathrm{C} / \mathrm{N}$ ratios are generally higher than 10 and never exceed 50. Nevertheless, some intervals, especially in the distal environment (DN-2), present $\mathrm{C} / \mathrm{N}$ values lower than 10 (Fig. 6). Such low values could be attributed to a notable contribution of nitrogen-rich $\mathrm{OM}$ of marine origin. However, because most of the nitrogen is known to be recycled during early diagenesis ([Tyson, 1995]), such ratio values might also be consistent with terrestrial OM originally presenting high $\mathrm{C} / \mathrm{N}(>10)$ but strongly altered before burial ( [Waples, 1977 and Müller, 1977]). These considerations mean that without other arguments (e.g. petrographic observations), $\mathrm{C} / \mathrm{N}$ ratio values must be used carefully for $\mathrm{OM}$ precursor characterisation.

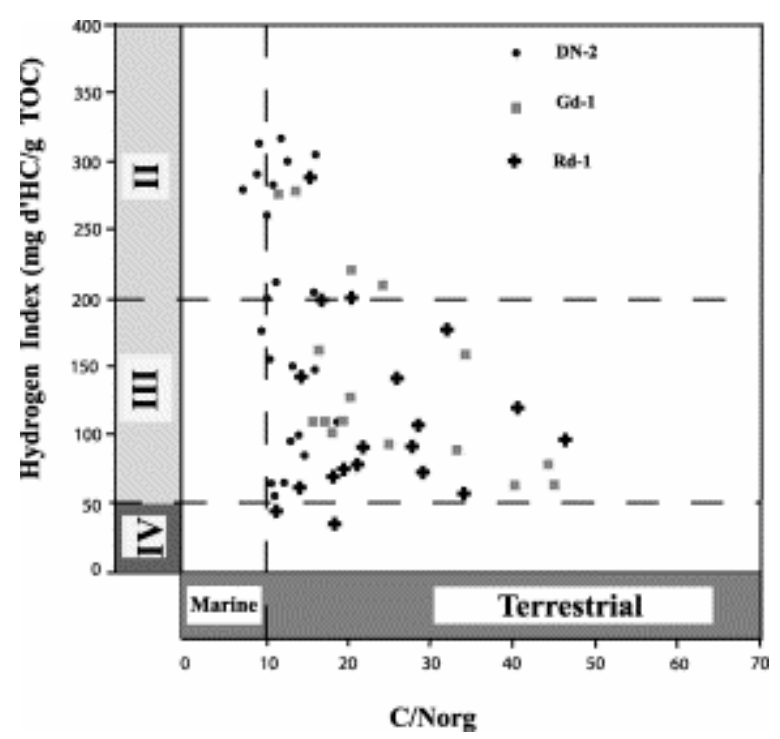

Fig. 6. Total organic carbon and nitrogen ratio $(\mathrm{TOC} / \mathrm{N})$ vs hydrogen index $(\mathrm{HI})$ indicating that the maximum of the samples are plotted within the area of terrestrial domain/type III.

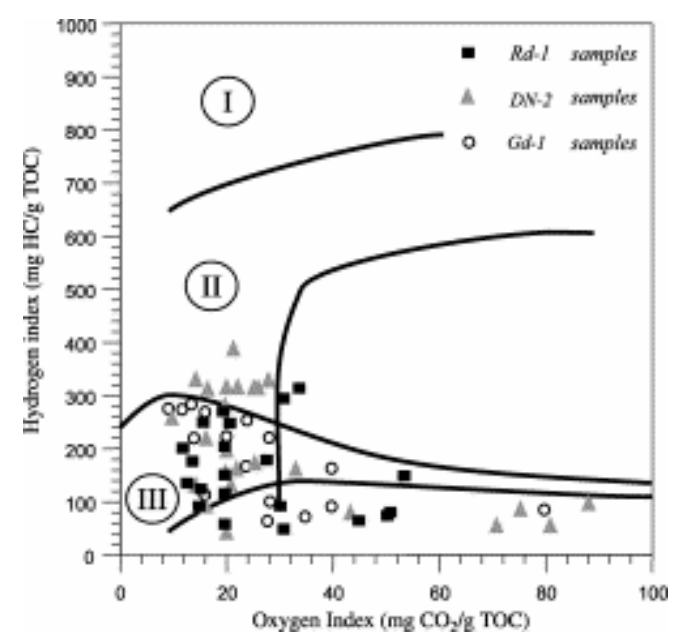

Fig. 7. Location of the studied samples in the hydrogen index-oxygen index diagram (modified from Espitalié et al., 1985). 
HI values are generally low (often $<300 \mathrm{mg} \mathrm{HC} \mathrm{g}^{-1} \mathrm{TOC}$ ) in the studied wells, and kerogen typing based on a HI vs OI diagram indicates a predominance of type III OM (Fig. 7). Nevertheless, some samples, mainly from the western part of the study area (DN-2 well), present relatively high $\mathrm{HI}$ values $\left(>300 \mathrm{mg} \mathrm{HC} \mathrm{g}^{-1} \mathrm{TOC}\right)$ that plot in the field of type II kerogens. In contrast, a part of the samples contain a hydrogen-depleted and oxygen-rich material that can thus be classified in the IV type OM. At the moderate degree of maturity reached by the samples (see below), such features probably indicate land-derived OM and/or strongly degraded OM of marine origin ([Tissot and Welte, 1984 and Bordenave, 1993]).

HI does not correlate significantly with TOC values (correlation coefficient: $r^{2}=0.59$ in DN-2; $r^{2}=0.037$ in Gd- $1 ; r^{2}=0.451$ in Rd-1). The slightly better correlation observed for the DN-2 well certainly reflects the already stressed and greater contribution of hydrogen-rich marine $\mathrm{OM}$ in the studied sediments at that site. The rather high mean $\mathrm{HI}$ value of $190 \mathrm{mg} \mathrm{HC} \mathrm{g}$ TOC in DN-2 compared to those of 133 in Rd-1 and 159 in Gd-1, is consistent with this interpretation. In contrast, the low mean HI values in the Rd-1 and Gd-1 wells might be indicative of high terrestrial inputs and/or extensive $\mathrm{OM}$ alteration. This point is further discussed later.

Palynofacies analyses indicate a strong predominance of amorphous organic matter (AOM) (more than 60\%) in all the studied samples (Fig. 5). The corresponding particles can be classified into two main groups. The first group is composed of non-fluorescent gelified AOM mainly dominated by rounded particles with sizes ranging from 25 to $40 \mu \mathrm{m}$ and generally presenting sharp contours ( Plate 1a). Their content is variable in the samples but decreases from the Rd-1 to the DN-2 well. The second group is represented by granular AOM (grAOM) particles having the same form and size as those of the first group (Plate 1b). Although all the particles of the latter group present essentially the same appearance under transmitted white

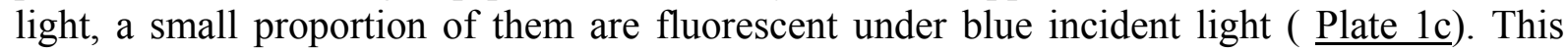
fluorescence suggests an oil-prone composition. Unlike gelified AOM, the percentage of grAOM decreases landward, i.e. from DN-2 to Rd-1.

The structured OM consists exclusively of higher plant debris $(\underline{\text { Plate } 1 \mathrm{~d}-\mathrm{f}})$ at different states of diagenetic alteration, well shown by their partly preserved original structures. Indeed, beginning with translucent or yellow coloured ligno-cellulosic debris of 35-50 $\mu \mathrm{m}$ in size with still preserved cellular structures, different types of higher plant tissues can be recognised. Some of these particles display the onset of amorphisation. Gelified AOM appears to be derived from these particles, after complete amorphisation. The similar increase in ligno-cellulosic debris and gelified AOM towards the shoreline supports the relationship between these two types of debris. Cuticles and fluorescent spores and pollen, even present at a low level, are also characteristic of a proximal environment. Various gelified and opaque land-derived particles are also present in variable sizes $(12-50 \mu \mathrm{m})$. However, their relative percentages as well as those of well-preserved tissues increase landward, i.e. from DN-2 to Rd-1. 

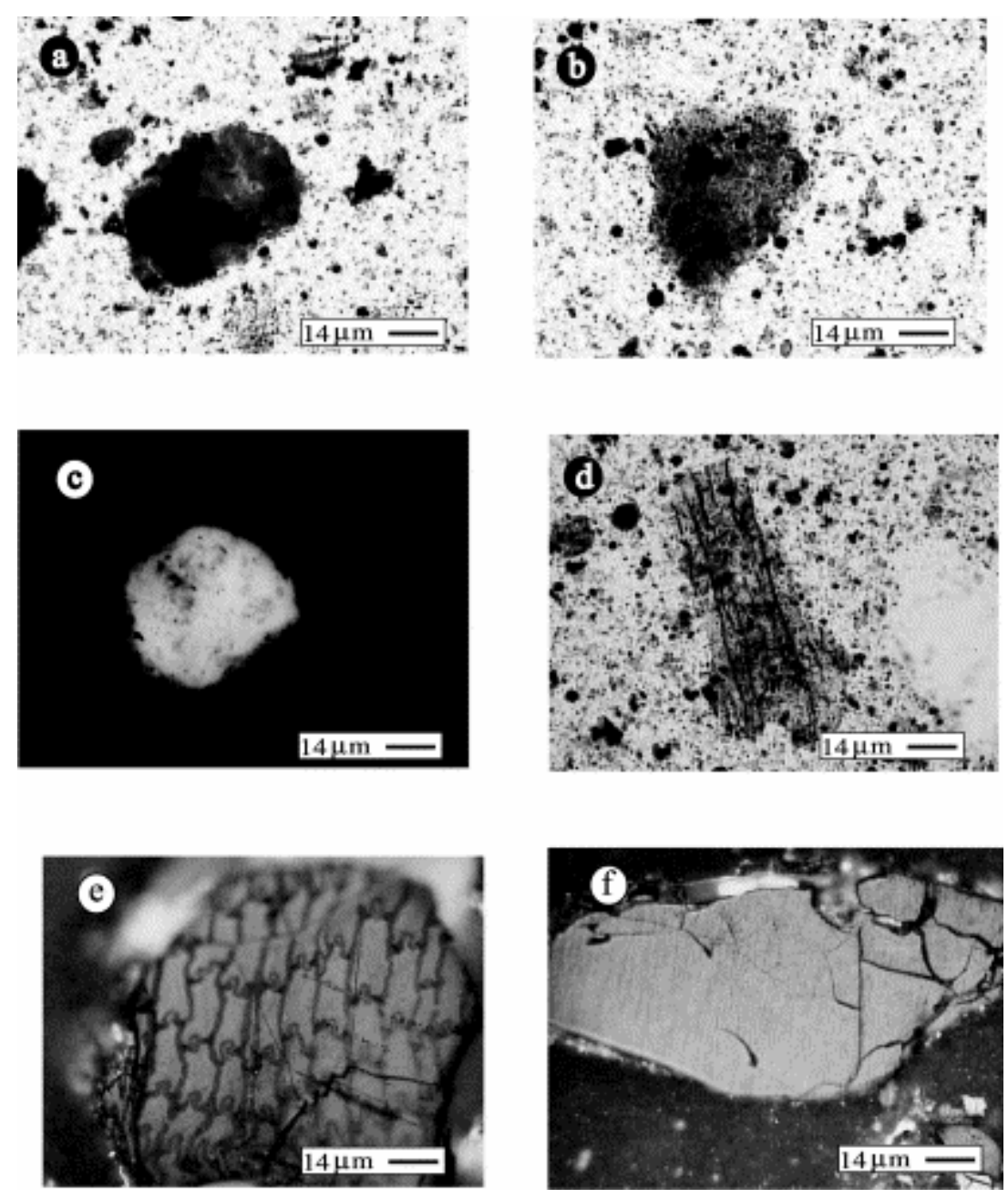

Plate 1. Optical microphotographs of the main organic constituents: (a) gelified AOM (transmitted light); (b) granular AOM (transmitted light); (c) granular AOM fluorescent in yellow (incident blue light); (d) translucent higher plant tissues (transmitted light); (e) telinite (incident white light); (f) collotelinite (incident white light).

As opaque particles cannot be characterised well by palynofacies analysis, a maceral analysis of densimetric concentrates which specifically targets these particles was carried out on the whole samples. The results of this analysis (Fig. 8) reveal that the particulate OM is mainly composed of vitrinite, with a predominance of collotelinite (44-69\%) and to a lesser extent of telinite $(<15 \%)$. The vitrinite particles have an angular shape and they are generally greater than $50 \mu \mathrm{m}$. Such characteristics exclude a strong fragmentation due to prolonged transportation, thus suggesting their sub-autochthonous origin. As usually observed in dispersed OM ([Dow, 1977, Robert, 1985, Alpern and Cheymol, 1978, Lo, 1992 and Barker and Pawlewicz, 1993]), reworked vitrinite is also present. Its particles are slightly oxidised and are rather small $(10-15 \mu \mathrm{m})$. These particles represent less than $10 \%$ in Gd-1 and more than $15 \%$ in some levels of Rd-1 and DN-2. As usually observed with reworked material, high amounts of small inertodetrinite particles are also present, particularly in DN-2. In the proximal area, i.e. in $\mathrm{Rd}-1$, the decrease in inertodetrinite amounts is accompanied by an increase in the amounts of large fusinite particles (up to $35 \%$; Fig. 8). From a general point of view, fusinite formation requires oxidising conditions in the depositional environment whereas inertodetrinite derives from inertinite mobilised by erosion of ancient sediments and undergoes some fragmentation during transport. Both macerals thus indicate an oxic and 
hydrodynamically active depositional environment. Macerals other than those originating from vascular plant tissues were seldom observed.

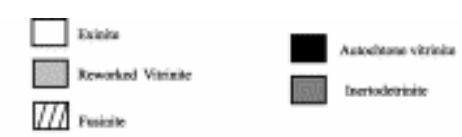

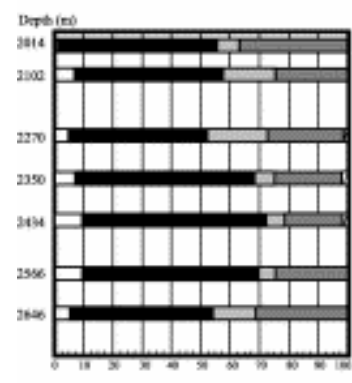

Bdiative pervenange of uge contuinams (So)

DN-2

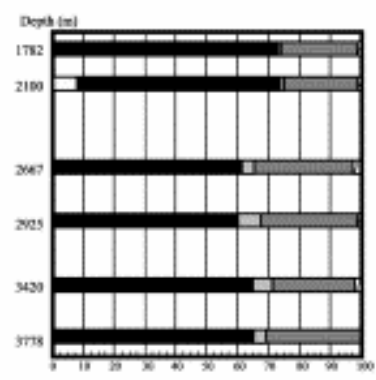

Relutive percetage of otg. wetsituent (s)

Od-1

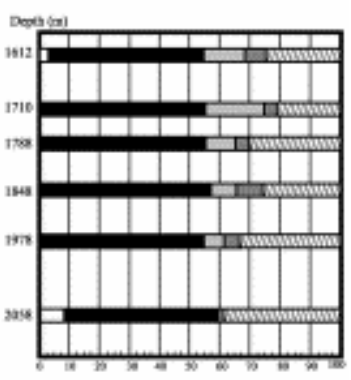

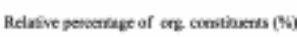

Rat

Fig. 8. Maceral composition performed on polished sections of densimetric concentrates of organic matter by optical microscopy (incident white and blue light). Note the predominance of vitrinite in all the samples. Fusinite content increase from distal (DN-2) to more proximal environment (Rd-1).
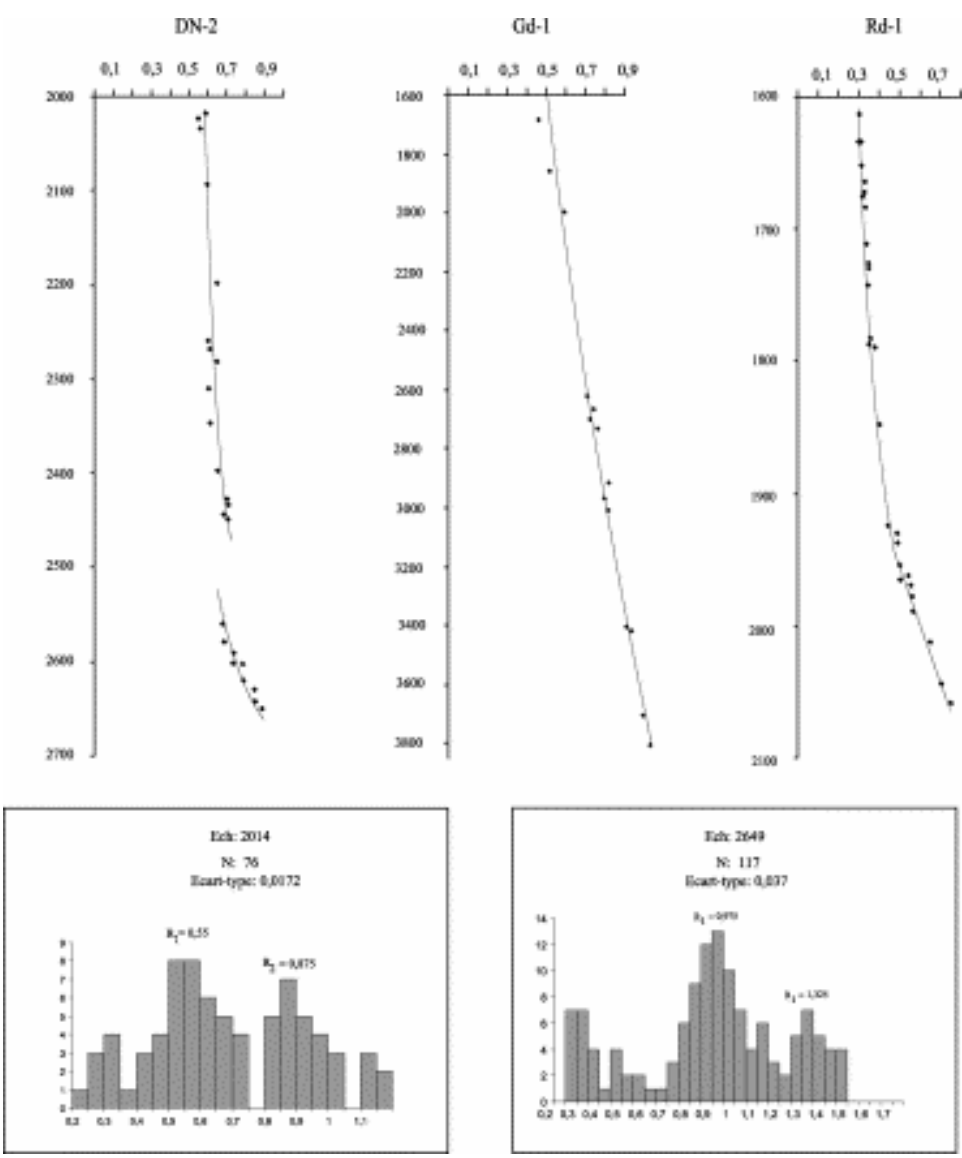

Fig. 9. Vitrinite reflectance vs depth and two examples of vitrinite reflectance histograms. 
An assessment of the level of maturity reached by the samples is provided by classical Vitrinite Reflectance measurement $\left(R_{0} \%\right.$; [Dow, 1977, Durand et al., 1986, Robert, 1985, Mukhopadhyay, 1994 and Suggate, 1998]) and $T_{\max }$ values determined by Rock-Eval pyrolysis ([Espitalié et al., 1985]). $R_{0}$ profiles (Fig. 9) show a gradual downward increase and vary from 0.30 to $0.75 \%$ in $\mathrm{Rd}-1$, from 0.30 to $0.80 \%$ in $\mathrm{Gd}-1$, and from 0.50 to $0.90 \%$ in $\mathrm{DN}-2$. $T_{\max }$ values vary between 435 and $445{ }^{\circ} \mathrm{C}$. As illustrated in a HI- $T_{\max }$ diagram (Fig. $\underline{10}$ ), the studied Cenomanian-Turonian series have reached a degree of thermal evolution globally corresponding to the first part of the oil window, i.e. from its onset to its middle part.

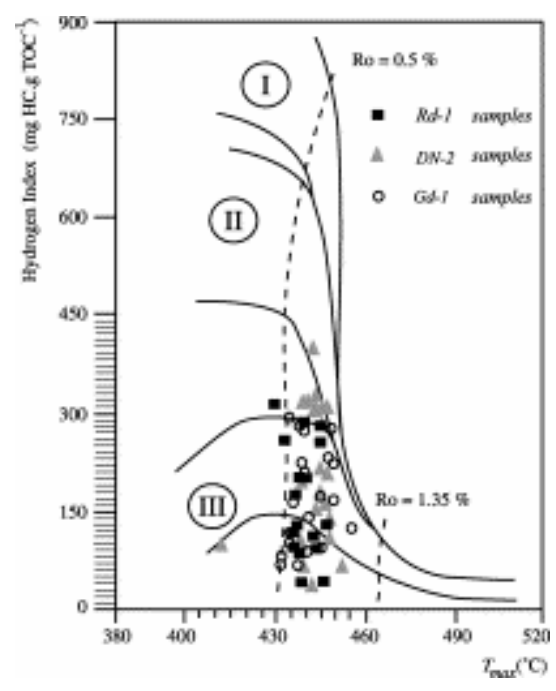

Fig. 10. Hydrogen index (HI) vs Rock-Eval $T_{\max }$ of Senegalese dispersed organic matter.

\section{Discussion}

\subsection{Organic matter source}

The composition of the dispersed OM in the studied sediments, and especially the abundance of well-preserved tissues typical of those derived from ligno-cellulosic plants, of vitrinite, inertinite particles and cuticles, suggest that OM inputs were dominated by terrestrial material. However, variations in maceral composition also highlight the role of the depositional setting in the transformation of ligno-cellulosic precursors. An anoxic environment was presumably responsible for OM gelification and vitrinite formation, whereas oxidising conditions were favourable to fusinite formation ([Stach et al., 1982 and Teichmüller, 1989]). The relative abundance of telinite and collotelinite particles belonging to the vitrinite maceral group in all the samples may also imply the existence of a fairly dense vegetation cover close to the site of deposition. Hence, humid paleoclimatic conditions favourable to forest development must have persisted in the hinterland during the deposition of the studied series. These climatic conditions were most probably also favourable for the presence of a fluvial system efficient for particulate OM transportation. Although the origin and even the diagenetic fate of the structured OM can be rather well established, there is still a doubt concerning the origin of structureless AOM. Because the marine OM is dominated by less resistant material (inherited from phytoplankton and bacteria) compared to terrestrial $\mathrm{OM}$, some authors consider that AOM generally derives from marine organisms ( [Lewan, 1986]). However, this assumption must be supported by other arguments because it is now 
well known that the structureless material can also be derived from higher plant debris, and macrophyte tissues ( [Tyson, 1995 and Bourdon et al., 2000]). In this study the two kinds of AOM particles that are distinguished (granular and gelified AOM) suggest the two following major genetic hypotheses. On the one hand, the two types of AOM particles can have the same origin but were preserved in different conditions. On the other hand, these two types of particles might have different precursors and so additionally different reactivities in the depositional environment. The first hypothesis is less plausible because it is difficult to support different behaviours of the same organic precursor in similar diagenetic conditions. As described above, the thermal alteration of grAOM seems to be characterised by a fluorescence loss, while gelified AOM never fluoresces even in the low mature levels. In contrast to the previous type of amorphous debris, the clear association of the gelified AOM with well preserved ligno-cellulosic debris and the increase in the proportions of these particles towards the shoreline suggest that the amorphous material probably originates from the diagenetic transformation of land-derived plants. This hypothesis is fully supported by the existence of intermediate states of transformation between ligno-cellulosic debris and gelified AOM particles. In contrast, the fluorescent grAOM certainly forms from planktonic organisms, with no or limited terrestrial contribution, in the fully marine environment. From a general point of view, if one considers depositional conditions unfavourable to $\mathrm{OM}$ preservation, the predominance of terrestrial debris observed in the study area might result either from their initial predominance or from the further relative increase in their original contribution, due to the preferential alteration of autochthonous planktonic material. The gelified AOM that is now considered by some authors to have acquired its intrinsic resistance to degradation as a result of sulfuration by incorporation of $\mathrm{H}_{2} \mathrm{~S}$ ([Tribovillard et al., 1994, Boussafir and Lallier-Vergès, 1997 and Baudin et al., 1999]), thus should necessarily be indicative of anoxic conditions that might have developed at or near the sediment-water interface.

\subsection{Depositional environment and OM preservation}

According to different authors cited above, the Cenomanian-Turonian is commonly considered as a period of worldwide anoxia. An atmospheric $p \mathrm{CO}_{2}$ level 3-12 times higher than the pre-industrial $p \mathrm{CO}_{2}$ level, a general absence of permanent ice caps, extremely high sea levels and much warmer ocean than today constitute the global Cretaceous setting ([Berner, 1994 and Hay et al., 1997]). During this period the West African margin paleogeographic configuration was linked to Gondwana land dislocation and proto-Atlantic ocean formation. Previous study of the Cenomanian-Turonian formation in the Senegal basin, but in a much more distal environment (DSDP sites 367 and 368; Fig. 1), described a $150 \mathrm{~m}$ thick complex alternation of finely laminated shaly carbonates and black shales clearly representing pelagic sedimentation ( [ Herbin et al., 1987]). With TOC values which vary between 10 and $40 \%$ and $\mathrm{HI}$ values comprised between 600 and $800 \mathrm{mg} \mathrm{HC} \mathrm{g}^{-1} \mathrm{TOC}$, the $\mathrm{OM}$ is of typically planktonic — and partly bacterial — origin ([Herbin et al., 1987]). The richness in marine OM, well developed sedimentary laminations and the scarcity of benthic foraminifera point to the accumulation of these formations under oxygen poor conditions ( [Herbin et al., 1987]). All these features also appear typical of the well-known CenomanianTuronian formations as defined worldwide. High primary productivity related to upwelling processes followed with a global spread of the oxygen minimum zone ( [ $\underline{\text { Herbin and Deroo, }}$ 1982]) was first suggested to explain the richness in OM of the sediments deposited on the Senegal margin during this period. Recent organic biomarker studies support the development of sulfides in the photic zone, thus entailing the establishment of strongly dysoxic or even anoxic waters over the whole tropical and sub-tropical Atlantic, from the Brazilian to the 
West African margin ( [ Sinninghe Damsté and Köster, 1998]). At the same time, in the Tarfaya basin (Morocco), on the same passive margin as the Senegal basin, the presence of isorenieratene originating from green sulphur bacteria also points to the temporal establishment of euxinic conditions into the photic zone ( [Kolonic et al., 2002]). High HI values combined with molecular and petrological characteristics of the OM deposited in this context reveal its marine origin and good preservation state ( [Kolonic et al., 2002]).

In contrast, low pyrite contents and $\mathrm{S} / \mathrm{C}$ ratio values mostly lower than 0.36 suggest medium oxic conditions and thus, efficient oxygenation of the waters by current circulations during that time. In fact, the presence of inertodetrinite and reworked vitrinite clearly documents the occurrence of nearshore currents which transported these particles. In Rd-1, abundant fusinite indicates well-oxygenated conditions in the proximal area. In immature sediments, the impact of conditions unfavourable to $\mathrm{OM}$ preservation is also reflected by their fluorescence properties ([Tyson, 1995]). In general, fluorescent AOM is thought to be derived from wellpreserved planktonic OM deposited in an anoxic setting ( [Lewan, 1986]). In the study area, the marked predominance $(>90 \%)$ of non-fluorescent particles among those of grAOM, suggests extensive degradation of the original material. The rather low maturity level reached in a large part of the drilled formations (first part of the oil window) excludes the possibility that fluorescence extinction could be due to thermal alteration ( [Tissot and Welte, 1984, Brosse et al., 1990, Pradier et al., 1991 and Tyson, 1995]). Thus, the non-fluorescence of the grAOM is at least partly explained by extensive degradation of the original hydrogen-rich OM in oxic waters ( [Pilskaln, 1991]).

The relatively low to moderate TOC values of the studied sediments can at first be taken as an indication of low primary productivity ([Tissot and Welte, 1984, Demaison and Moore, 1980, Calvert, 1987 and Huc et al., 1992]). However, the basin (DSDP 367 and 368 sites) and platform series differ in another crucial factor than $\mathrm{OM}$ quantity and quality, namely the dilution of OM inputs by minerals. This very basic factor is likely to be very significant if one considers that the thickness of the black shale varies from a few centimetres to a few tens of meters in the basin, whereas it reaches several hundreds of meters and up to $1 \mathrm{~km}$ in the study area. In itself, mineral dilution is likely to account for a large part of the differences in TOC contents between the basin and the platform. The importance of this dilution factor stresses the crucial role played by the depositional environment on OM accumulation. This conclusion appears to be in general agreement with a previous statement made by [Sinninghe Damsté and Köster, 1998] who suggested that the restricted connection of the south Atlantic to the rest of the ocean might have promoted the development of euxinic waters and thus OM preservation. In the light of our results it is clear that such paleogeographic conditions did not exist on the Senegal shelf margin.

A synthesis of geochemical and petrographic data (Fig. 11) allows representation of lateral OM distributions according to terrestrial and marine precursors. All typical CenomanianTuronian facies were distinguished according to [Jones, 1987] concepts. The first facies ' $\mathrm{A}$ ' which is dominated by terrestrial and refractory OM is typical for a highly oxygenated environment. This area which was mainly affected by coastal and may be fluvial inputs, might correspond to a deltaic and/or littoral environment. For facies ' $\mathrm{B}$ ' which is characteristic of a transitional slope environment, the terrestrial $\mathrm{OM}$ is always dominant, although the medium was generally less oxygenated that for ' $A$ '. Facies ' $C$ ' corresponds to a fully marine environment where part of the AOM retained its fluorescence properties, presumably due to the development of more or less permanent anoxic conditions at the base of the water column. Fully anoxic conditions were obviously established basinward as revealed by the OM rich 
lateral equivalents penetrated by drilling at the 367 and 368 DSPD sites offshore Senegal. There high planktonic productivity and low energy hydrodynamic conditions favoured the development of anoxic waters and hence OM preservation.

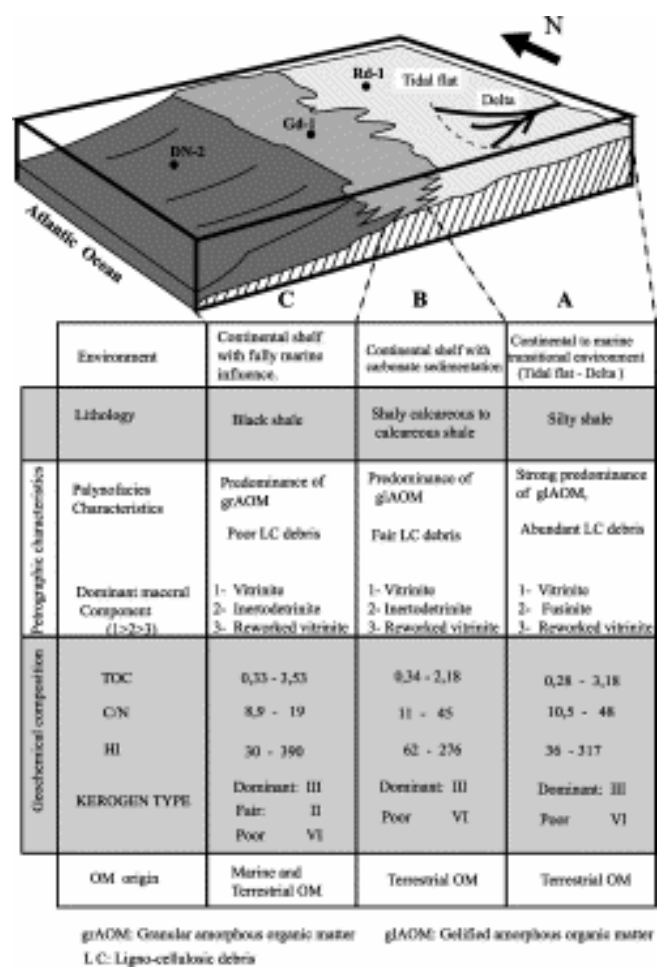

Fig. 11. Organic facies model and lateral repartition of Cenomano-Turonian depositional setting in Onshore Senegalese basin as deduced from petrographic and geochemical data.

\subsection{Source rocks characterisation and petroleum system}

Based on the Cenomanian-Turonian source rock characteristics in the distal part of the Senegal basin, it has long been suggested that this formation is the main source rock in the study area. However, its oil-generating potential has not yet been clearly estimated. Overall Rock-Eval and petrographic data on the studied sediments suggest a predominance of gas prone OM from terrestrial and marine origin, this latter material being represented by nonfluorescent amorphous kerogen. This gas prone potential is in general in agreement with most of the hydrocarbon discoveries in the study area which are composed of gas ([Nzoussi, 1998]). The rare oil prone levels evidenced in an OI vs HI diagram correspond to sediments from the DN-2 well that were deposited in a fully marine environment.

Thermal maturity indications given by $T_{\max }$ and vitrinite reflectance are in agreement and indicate that in all the Senegal platform, the OM has entered the oil window. The general trends observed in the basin show that the maturity conditions clearly improve southward, i.e. in Casamance, where Cenomanian-Turonian sediments are buried more deeply.

The oil and gas discovered in the study area are mainly found in Late Cretaceous sediments reservoirs (Maastrichtian). The latter which consist of thin and lenticular sandstones interbedded in shales, are characteristic of the prograding fluvio-deltaic environment developed during Late Cretaceous regression ([Nzoussi, 1998]). Tectonic complexity increases westward and results in slump features expressed by syn-sedimentary normal 
faulting and the development of associated 'rollover' anticlinal traps. The Mississippi and Niger delta are the best-known examples of such complex structures ( [Harding and Lowell, 1979]). Stratigraphic traps are likely to become more important targets in distal and deeper portions of the delta.

The origin and the migration pathway of the hydrocarbons accumulated in Maastrichtian formation are not yet clearly determined. No direct correlation has been established between Maastrichtian reservoired hydrocarbons and Cenomanian-Turonian source rocks. However, although not very rich, the latter appear to have the best generating potential in the study area. In addition, they have reached the minimum thermal level required for effective oil generation (this study). The Jurassic and Lower Cretaceous carbonate platform has never been totally penetrated but the few wells that have been drilled have revealed poor OM contents. The only other horizons which contain some $\mathrm{OM}$ are the Campanian and Lower Maastrichtian. However, recent studies proved that they have not reached the oil (and gas) window(s) ([Nzoussi, 1998]). Thus, it can be assumed that the petroleum system in the study area is Cretaceous and is composed of Cenomanian-Turonian source rocks and Maastrichtian reservoirs ( Fig. 12). Hydrocarbon migration may have been controlled by the movement of the listric faults that affect all the Meso-Cenozoic cover. However, these assumptions need to be verified by oil-source rock and reservoir correlations.

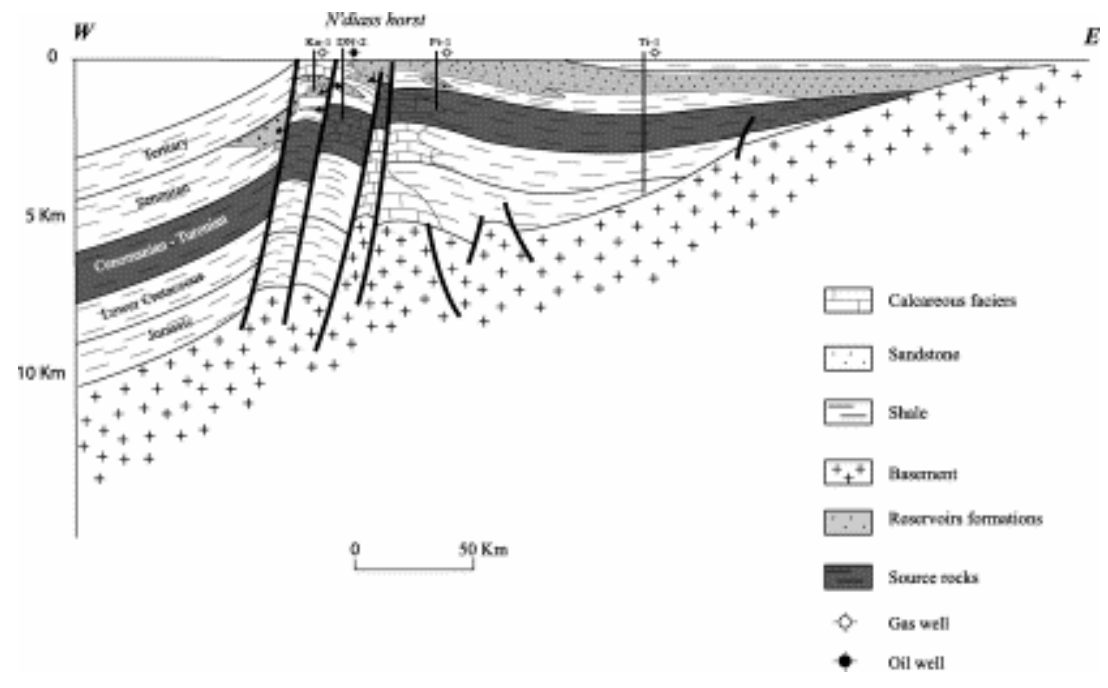

Fig. 12. Thies-Diam Niadio cross-section illustrating relationship between CenomanianTuronian source rocks and Maastrichtian sandstones reservoirs. Normal faults represent the main migration pathway.

\section{Conclusion}

The petrographic and bulk geochemical characterisation of the OM from CenomanianTuronian formations in the Senegal margin basin, defines the sources, preservation conditions and hydrocarbon potential. Globally, the sediments show rather low to moderate OM contents. Notable proportions of well-preserved higher plant debris clearly indicate terrestrial inputs. This observation appears in agreement with both the predominance of type III OM as revealed in a $\mathrm{HI}$ and $\mathrm{OI}$ diagram and relatively high $\mathrm{C} / \mathrm{N}$ values. The low $\mathrm{TOC}$ values are difficult to interpret according to one single factor. Nevertheless, it is clear that the paleogeographic setting appears to be the main factor which determined OM quality and 
abundance. This factor explains both oxic waters with littoral water influences and high clastic sediment inputs. With respect to the southern area of the basin (Casamance), where Cenomanian-Turonian sediments were deposited in an anaerobic fully marine environment, there is a south-north lateral transition towards the open ocean where anoxic conditions have prevailed.

Moderate bioproductivity, poor OM preservation conditions, marked dilution of the primary organic inputs and moderate maturity (onset of the oil-window) limit the hydrocarbon potential of the studied formation. Based on basin evolution during the post-rift phase, the petroleum system reflects all the characteristics of 'the continental platform type system' defined by [Perrodon, 1992 and Perrodon, 1995]. The essential elements are CenomanianTuronian source rocks, Maastrichtian sandstone reservoirs and rollover structural traps related to syn-sedimentary tectonic.

Compared to common Cenomanian-Turonian formations assumed to have been deposited in an anaerobic marine environment with restricted water circulations, the specificities of the studied area appear entirely linked to local paleogeographic factors, namely the marginolittoral situation of its depositional setting that mostly entailed very abundant terrestrial inputs (with reworked OM particles) and oxygenated waters.

\section{Acknowledgements}

The authors would like to thank A.O. Wane and J. Medou from the Senegalese Petroleum Corporation for allowing us to access the data and collect the samples. They are grateful to M. Hatton and D. Keravis for technical assistance and to M. Boussafir for fruitful discussions. They also thank E. Jolivet who improves the manuscript English. The authors also thank the reviewers for their constructive comments on the initial version of the manuscript.

\section{References}

Alpern and Cheymol, 1978. B. Alpern and D. Cheymol, Reflectance et fluorescence des organoclastes du Toarcien du bassin de Paris en fonction de la profondeur et de la température. Revue Institut Français du Pétrole XXXIII 4 (1978), pp. 515-535.

Arthur and Schlanger, 1979. M.A. Arthur and S.O. Schlanger, Cretaceous "Oceanic Anoxic Events" as causal factors in development of reef-reservoired giant oil fields. AAPG Bulletin 636 (1979), pp. 870-885.

Barker and Pawlewicz, 1993. C.E. Barker and M.J. Pawlewicz, An empirical determination of the minimum number of measurements needed to estimate the mean random vitrinite reflectance of disseminated organic matter. Organic Geochemistry 206 (1993), pp. 643-651.

Baudin et al., 1999. F. Baudin, N. Tribovillard, F. Laggoun-Défarge, E. Lichtfouse, O. Monod and S. Gardin, Depositional environment of a Kimmeridgian carbonate "black band" (Akkuyu Formation, south-western Turkey). Sedimentology 46 (1999), pp. 589-602.

Berner, 1994. R.A. Berner, Geocarb II: a revised model of atmospheric $\mathrm{CO}_{2}$ over phanerozoic time. American Journal of Science 294 (1994), pp. 56-91. 
Bordenave, 1993. M.L. Bordenave. Applied petroleum geochemistry, Technip, Paris (1993) p. 524 .

Bourdon et al., 2000. S. Bourdon, F. Laggoun-Défarge, J.-R. Disnar, O. Maman, B. Guillet, S. Derenne and C. Largeau, Organic matter sources and early diagenetic degradation in a tropical peaty marsh (Tritrivakely, Madagascar). Implications for environmental reconstruction during the Sub-Atlantic. Organic Geochemistry 31 (2000), pp. 421-438.

Boussafir and Lallier-Vergès, 1997. M. Boussafir and E. Lallier-Vergès, Accumulation of organic matter in the kimmeridge clay formation $(\mathrm{KCF})$ : an update fossilisation model for marine petroleum source-rocks. Marine and Petroleum Geology 141 (1997), pp. 75-83.

Brosse et al., 1990. E. Brosse, A. Riva, S. Santucci, M. Bernon, J.-P. Loreau, A. Frixa et al., Some sedimentological and geochemical characters of the late Triassic Noto Formation source rock in the Ragusa basin (Sicily). Organic Geochemistry 16 4-6 (1990), pp. 715-734.

Busson, 1972. G. Busson, Principes, méthodes, et résultats d'une étude stratigraphique du Mésozoïque saharien. Mémoire Muséum Histoire Naturelle Paris, série C XXVI (1972), p. 441.

Busson and Cornée, 1996. G. Busson and J. Cornée. Société Géologique du Nord, Publication 23Société Géologique du Nord, Publication 23 (1996).

Calvert, 1987. S.E. Calvert, Oceanographic controls on the accumulation of organic matter in marine sediments. In: J. Brooks and A.J. Fleet, Editors, Geological Society of London, Special Publication, 26Geological Society of London, Special Publication, 26 (1987), pp. 137-151.

Demaison and Moore, 1980. G.J. Demaison and G.T. Moore, Anoxic environments and oil source bed genesis. AAPG Bulletin 64 (1980), pp. 1179-1209.

Dillon and Sougy, 1974. W.P. Dillon and J. Sougy, Geology of West Africa and Canary and Cape Verde Islands. In: A.E.M. Nairn and F.G. Stehli, Editors, The ocean basins and margins, 2, Plenum Publication Corp, New York (1974), pp. 315-390.

Dow, 1977. W.G. Dow, Kerogen studies and geological interpretation. Journal of Geochemical Exploration 72 (1977), pp. 79-99.

Durand et al., 1986. B. Durand, B. Alpern, J.L. Pittion and B. Pradier, Reflectance of vitrinite as a control of thermal history of sediments. In: J. Burrus, Editor, Thermal modeling in sedimentary basins, Technip, Paris (1986), pp. 441-474.

Espitalié et al., 1985. J. Espitalié, G. Deroo and F. Marquis, La pyrolyse Rock-Eval et ses applications. Revue Institut Français du Pétrole, part I 10 (1985), pp. 563-578. J. Espitalié, G. Deroo and F. Marquis, La pyrolyse Rock-Eval et ses applications. Revue Institut Français du Pétrole, part II 40 (1985), pp. 755-784.

J. Espitalié, G. Deroo and F. Marquis, La pyrolyse Rock-Eval et ses applications. Revue Institut Français du Pétrole, part III 41 (1985), pp. 467-481. 
Falvey, 1974. D.A. Falvey, The development of continental margin in plate tectonic theory. Australian Petroleum Exploration Association Journal (1974), pp. 95-106.

de Graciansky et al., 1982. P.C. de Graciansky, E. Brosse, G. Deroo, J.P. Herbin, L. Montadert, C. Müller et al., Les formations d'âge crétacé de l'Atlantique nord et leur matière organique: paléogéographie et milieux de dépôt. Revue Institut Français du Pétrole 373 (1982), pp. 275-338.

de Graciansky et al., 1984. P.C. de Graciansky, G. Deroo, J.P. Herbin, L. Montadert, C. Müller, A. Schaaf et al., Ocean-wide stagnation episode in the late Cretaceous. Nature $\mathbf{3 0 8}$ (1984), pp. 346-349.

Hay et al., 1997. W.W. Hay, R.M. Deconto and C.N. Wold, Climate: is the past the key to the future?. Geologsche Rundschau 86 (1997), pp. 471-491.

Harding and Lowell, 1979. T.P. Harding and J.D. Lowell, Structural styles, their platetectonic habitats, and hydrocarbon traps in petroleum provinces. AAPG Bulletin 63 (1979), pp. 1016-1058.

Herbin and Deroo, 1982. J.P. Herbin and G. Deroo, Sédimentologie de la matière organique dans les formations du mésozoïque de l'Atlantique nord. Bulletin de la Société Géolologique de France 73 (1982), pp. 497-510.

Herbin et al., 1986. J.P. Herbin, L. Montadert, C. Müller, R. Gomez, J. Thurow and J. Wiedmann, Organic-rich sedimentation at the Cenomanian-Turonian boundary in oceanic and coastal basins in the North Atlantic and Tethys. Geological Society of London, Special Publication, 21 (1986), pp. 389-422.

Herbin et al., 1987. J.P. Herbin, C. Müller, P.C. de Graciansky, T. Jacquin, F. Magniez-Jannin and P. Unternehr, Cretaceous anoxic events in the South Atlantic. Revue Brasileira de Geociencias 17 (1987), pp. 92-99.

Huc et al., 1992. A.Y. Huc, E. Lallier-Vergès, P. Bertrand, B. Carpentier and D.J. Hollander, Organic matter response to change of depositional environment in Kimmeridgian shales, Dorset, UK. In: J. Whelan and J. Farrington, Editors, Productivity, accumulation, and preservation of organic matter in recent and ancient sediments, Columbia University Press, New York (1992), pp. 469-486.

ICCP, 1971. International Committee of Coal Petrology. International handbook of coal petrography (2nd ed ed.), CNRS, Paris (1971).

Jenkyns, 1980. H.C. Jenkyns, Cretaceous anoxic events: from continents to oceans. Journal of the Geological Society, London 137 (1980), pp. 171-188.

Jones, 1987. R.W. Jones, Organic facies. In: J. Brooks and D.H. Welte, Editors, Advances in petroleum geochemistry, Academic Press, London (1987), pp. 1-80.

Kinsman, 1975. D.J.J. Kinsman, Rift valley basins and sedimentary history of trailing continental margin. In: A.C. Fisher and J. Judson, Editors, Petroleum and global tectonics, Princeton University Press, Princeton, NJ (1975), pp. 83-128. 
Kolonic et al., 2002. S. Kolonic, J.S. Sinninghe Damsté, M.E. Böttcher, M.M.M. Kuypers, W. Kuhnt, B. Beckmann et al., Geochemical characterization of Cenomano/Turonian Black shales from the Tarfaya basin (SW Morocco). Relationships between palaeoenvironmental conditions and early sulphurization of sedimentary organic matter. Journal of Petroleum Geology 253 (2002), pp. 325-350.

Lafargue et al., 1998. E. Lafargue, F. Marquis and D. Pillot, Rock-Eval 6 applications in hydrocarbon exploration, production, and soil contamination studies. Revue Institut Français du Pétrole 564 (1998), pp. 421-437.

Lancelot, 1980. Y. Lancelot, Birth and evolution of the "Atlantic Tethys". Mémoire Bureau Recherche Géolologique et Minière 115 (1980), pp. 215-223.

Lewan, 1986. M.D. Lewan, Stable carbon isotopes of amorphous kerogens from phanerozoic sedimentary rocks. Geochimica et Cosmochimica Acta 50 (1986), pp. 1581-1591.

Lo, 1992. H.B. Lo, Identification of Indigenous vitrinites for improved thermal maturity evaluation. Organic Geochemistry 183 (1992), pp. 359-364.

McKenzie, 1978. D. McKenzie, Some remarks on the development of sedimentary basins. Earth and Planetary Sciences Letters 40 (1978), pp. 25-32.

Michaud, 1984. Michaud, L. (1984). Les milieux sédimentaires crétacés du Sénégal et leur évolution diagénétique (étude de subsurface) (p. 285). Unpublished $\mathrm{PhD}$ Thesis, University of Aix-Marseille, 3.

Minster et al., 1992. T. Minster, Y. Nathan and A. Ravh, Carbon and sulfur relationships in marine Senonian organic-rich, iron-poor sediments from Israel-a case study. Chemical Geology 97 (1992), pp. 145-161.

Morse and Berner, 1995. W.J. Morse and A.R. Berner, What determines sedimentary C/S ratio. Geochimica et Cosmochimica Acta 59 (1995), pp. 1073-1077.

Mukhopadhyay, 1994. P.K. Mukhopadhyay, Vitrinite reflectance as maturity parameter: petrographic and molecular characterisation and its applications to basin modeling. In: P.K. Mukhopadhyay and W.G. Dow, Editors, ACS Symposium Series No. 570ACS Symposium Series No. 570, American Chemical Society, Washington, DC (1994), pp. 1-24.

Müller, 1977. P.J. Müller, C/N ratios in Pacific deep-sea sediments: effect of inorganic ammonium and organic nitrogen compounds sorbed by clays. Geochimica et Cosmochimica Acta 41 (1977), pp. 765-776.

Nzoussi, 1998. Nzoussi, M. P. (1998). Etude des faciès réservoirs de la zone de Thiès Diam Niadio (Sénégal) (p. 69). Unpublished Master Memor., University of Dakar.

Perrodon, 1992. A. Perrodon, Petroleum systems: models and application. Journal of Petroleum Geology 153 (1992), pp. 319-326.

Perrodon, 1995. A. Perrodon, Petroleum systems and global tectonics. Journal of Petroleum Geology 184 (1995), pp. 471-476. 
Pilskaln, 1991. C.H. Pilskaln. Biogenic aggregate sedimentation in the black sea basin, Kluwer Academic, Dordrecht (1991) pp. 293-306 .

Pitman and Talwani, 1972. W.C. Pitman and M. Talwani, Sea floor spreading in north Atlantic. American Geological Society Bulletin 83 (1972), pp. 619-646.

Pradier et al., 1991. B. Pradier, P. Bertrand, L. Martinez and F. Laggoun-Défarge, Fluorescence of organic matter and thermal maturity assessment. Organic Geochemistry 174 (1991), pp. 511-524.

Raiswell and Berner, 1985. R. Raiswell and R.A. Berner, Pyrite formation in euxinic and semi-euxinic sediments. American Journal of Sciences 285 (1985), pp. 710-724.

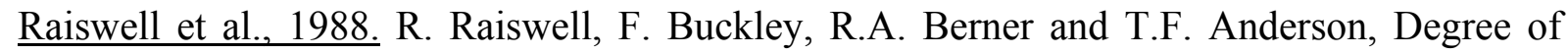
pyritization of iron as a paleoenvironmental indicator of bottom-water oxygenation. Journal of Sedimentary Petrology 58 (1988), pp. 710-724.

Robert, 1985. P. Robert, Histoire géothermique et Diagenèse thermique. Bulletin Centre de Recherche Exploration-production Elf-Aquitaine 8 (1985), pp. 133-160.

Sinninghe Damsté and Köster, 1998. J.S. Sinninghe Damsté and J. Köster, A euxinic southern North Atlantic Ocean during the Cenomanian/Turonian oceanic anoxic event. Earth and Planetary Sciences Letters 158 (1998), pp. 165-173.

Stach et al., 1982. E. Stach, M.T. Mackowsky, M. Teichmüller, G.H. Taylor, D. Chandra and R. Teichmüller. Stach's textbook of coal petrology, Gebrüder Borntraeger, Berlin (1982) p. 535 .

Suggate, 1998. R.P. Suggate, Relations between depth of burial, vitrinite reflectance and geothermal gradient. Journal of Petroleum Geology 211 (1998), pp. 5-32.

Thiede and Van Andel, 1977. J. Thiede and T.H. Van Andel, The palaeoenvironment of anaerobic sediments in the late Mesozoic south atlantic ocean. Earth and Planetary Science Letters 333 (1977), pp. 301-309.

Teichmüller, 1989. M. Teichmüller, The genesis of coal from the viewpoint of coal petrology. International Journal of Coal Geology 12 (1989), pp. 1-87.

Tissot, 1979a. B. Tissot, La répartition mondiale des combustibles fossiles. La Recherche, Paris 10410 (1979), pp. 984-991. Abstract-INSPEC

Tissot, 1979b. B. Tissot, Effects on prolific petroleum source rocks and major coal deposits caused by sea-level changes. Nature 277 (1979), pp. 463-465.

Tissot and Welte, 1984. B.P. Tissot and D.H. Welte. Petroleum formation and occurrence, Springer, Berlin (1984) p. 699 . 
Tribovillard et al., 1994. N.P. Tribovillard, A. Desprairies, E. Lallier-Vergès, P. Bertrand, J.R. Disnar, B. Pardier and N. Moureau, Geochemical study of organic-rich cycles from kimmeridge clay formation of Yorshire. Palaeogeography, Palaeoclimatology, Palaeoecology 108 (1994), pp. 165-181.

Tyson, 1995. R.V. Tyson. Sedimentary organic matter. Organic facies and palynofacies, Chapman \& Hall, London (1995) p. 615.

Villeneuve and Da Rocha Araujo, 1984. M. Villeneuve and P.R. Da Rocha Araujo, La stratigraphie du bassin paléozoïque de Guinée (Afrique de l'Ouest). Bulletin de la Société Géologique de France 32 (1984), pp. 29-40.

Waples, 1977. D.W. Waples, C/N ratios in source rock studies. Colorado School of Mines Mineral Industries bulletin 205 (1977) 7 pp .

Waples, 1983. D.W. Waples, Reappraisal of anoxia and organic richness, with emphasis on cretaceous of North Atlantic. AAPG Bulletin 676 (1983), pp. 963-978. 